\title{
Cardiopulmonary Function During Six Weeks Exposure to Simulated High Altitude in Growing Rats
}

\author{
Yuji Takemura, Shigeru Sugano, Hisashi Hirose \\ and Hiroshi SAWAzAKI \\ Department of Animal Environmental Physiology, \\ Faculty of Agriculture, The University \\ of Tokyo, Bunkyo-ku, Tokyo 113
}

(Received December 27, 1983)

\begin{abstract}
An attempt was made, by using a control chamber, to elucidate how the cardiopulmonary function of the growing rat is affected by chronic exposure to a hypoxic condition. Thirty-five male Wistar rats were divided into 7 groups at 5 weeks old : $\mathrm{C}_{0}$, examined at 5 weeks old; $T_{3}, T_{6}$, exposed to a hypobaric-hypoxic condition (simulated $2,500 \mathrm{~m}$ altitude) from 5 to 8 and 11 weeks old; $T_{17}$, exposed to the hypobaric-hypoxic condition from 5 to 11 weeks old then kept at a normobaric-normoxic condition (simulated sea level) until 22 weeks old; $C_{3}, C_{6}, C_{17}$, control groups for $T_{3}, T_{6}, T_{17}$, respectively, kept at the normobaric-normoxic condition. Ambient temperature, relative humidity, and $\mathrm{CO}_{2}$ concentration were maintained at $25^{\circ} \mathrm{C}, 60 \%$, and $500-1,500 \mathrm{ppm}$, respectively. Morphological, electrocardiographical, and haematological examinations were performed under the sea level condition. The exposure depressed the gain in body weight progressively and prolonged the QT interval. The increase in the heart weight of the exposed group continued after the return to the sea level, but the increased adrenal weight during the exposure was restored by the return. Notable increases in erythrocyte count, $\mathrm{Hb}$ concentration, $\mathrm{Hct}$ value, and the weight of the right ventricular free wall were observed in $T_{3}$. However, these increases were depressed thereafter. Enlargement of the variation in mean QRS axis and increases in $\mathrm{MCV}, \mathrm{MCH}$, and the lung weight/body weight were revealed in $T_{6}$. In general, the results obtained in this experiment were similar to those observed in a natural high altitude environment. It was considered that the most influential factor for the cardiopulmonary function at high altitudes was the decrease in oxygen tension and that the animals altered their physiological conditions for achieving new stability through the process of adaptation to a high altitude environment.

Jpn. J. Zootech. Sci., 55 (7): 508-514, 1984
\end{abstract}

It is well known that physiological adaptation in the cardiopulmonary system occurs in man and animals native to or exposed to high altitudes. It has been presumed that the cardiopulmonary changes observed at high altitudes are mainly concerned with the level of oxygen tension ${ }^{1,2,3}$. In a natural high altitude environment, the living body is affected by a complex of many meteorological factors. Therefore, this investigation was designed to discriminate only the effects of oxygen tension from those of other factors by using a control chamber ${ }^{4}$. The aim of the present study is to elucidate how the cardiopulmonary function of the growing rat is affected by chronic exposure to a hypoxic condition. 


\section{Materials and Methods}

Thirty-five male Wistar rats were raised for one week preliminarily from 4 to 5 weeks old in a control chamber (Shimadzu, SCA-102Z) * under a normobaric-normoxic condition (simulated sea level), and then divided into the following 7 groups: $\mathrm{C}_{0}$, non-exposed and examined at 5 weeks old; $T_{3}, T_{6}$, exposed to a hypobaric-hypoxic condition equivalent to $2,500 \mathrm{~m}$ altitude from 5 weeks old and examined at 8 and 11 weeks old, respectively; $T_{17}$, exposed to the hypobaric-hypoxic condition from 5 to 11 weeks old, and then raised under the normobaric-normoxic condition and examined at 22 weeks old; $\mathrm{C}_{3}, \mathrm{C}_{6}, \mathrm{C}_{17}$, control groups for $\mathrm{T}_{3}, \mathrm{~T}_{6}, \mathrm{~T}_{17}$, respectively, raised under the normobaric-normoxic condition.

The chamber was composed of main- and sub-cabinets, in which the simulations of $2,500 \mathrm{~m}$ altitude and sea level conditions were performed, respectively. The exposed groups were returned to the sea level condition every two days for $1.5 \mathrm{~h}$ to be fed according to normal procedures for rats and to be measured for body weight with the control groups. Ambient temperature, relative humidity, and $\mathrm{CO}_{2}$ concentration were continuously maintained at $25^{\circ} \mathrm{C}, 60 \%$, and $500-1,500 \mathrm{ppm}$, respectively, and light control (12 L and $12 \mathrm{D}$ ) was also performed.

All observations were carried out on the rats anesthetized by urethane (primal dose $0.8 \mathrm{~g} / \mathrm{kg}$ i.p. and supplemental dose $0.4 \mathrm{~g} / \mathrm{kg}$ s. c.) under a normobaric-normoxic condition out of the chamber. The exposed groups were examined by the next day of their return to the sea level at each examination. Electrocardiograms in limb leads were recorded with a biophysiograph (Sai-ei, 180 system). Mean QRS axis was calculated from the records of LI and LIII, and QT and PP intervals were measured from the record of LII. For the blood samples collected from the abdominal aorta, erythrocyte count, $\mathrm{Hb}$ concentration, and $\mathrm{Hct}$ value were measured with a Micro Cell Counter (Toa Medical Electric, CC-108), by azide methaemoglobin method, and by micro capillary method, respectively. Thereafter, all rats were killed by bleeding and the weights of the heart, the lungs, and the adrenal glands in raw material were measured by Mettler (Siebel-Seiko, H-10). After the heart was fixed in a $10 \%$ neutral formalin solution for one week, the weights of the right ventricular free wall $(R)$ and the left ventricular free wall plus the ventricular septum $(L+S)$ were measured according to Fulton's method ${ }^{5}$.

\section{Results}

The increase in body weight of the exposed group was depressed progressively in accordance with the time of exposure as shown in Fig. 1.

Though the adrenal weight of the exposed group increased during exposure, it was reduced by the return to sea level (Fig. 2).

\footnotetext{
*installed in the Center of Environment Regulation System for Biology, Faculty of Agriculture, The University of Tokyo.
} 


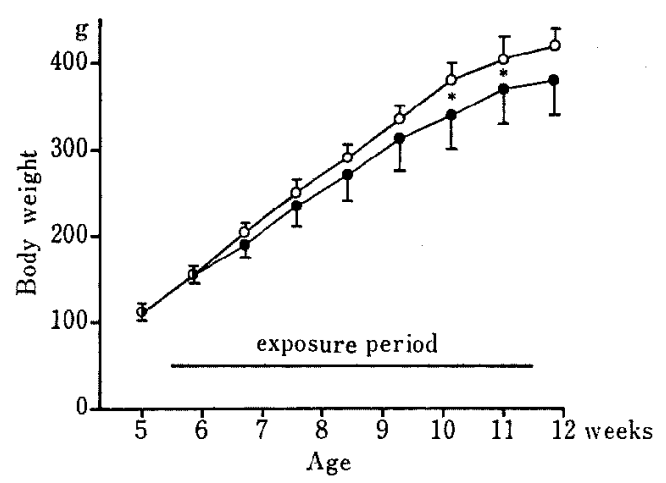

Fig. 1. Growth curve in body weight in control (O) and exposed (•) groups. Each mark represents a mean $\pm S$. D.. *: significant difference between control and exposed groups $(P<0.05)$.

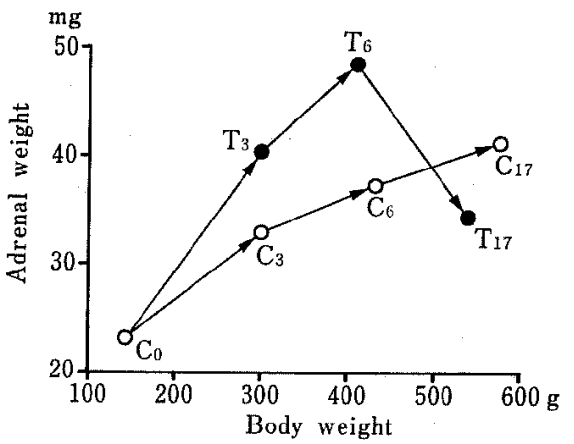

Fig. 2. Correlation chart of adrenal weight and body weight. The line which connects the marks (mean values in each group) with the arrows indicates the changing process of the correlation between both parameters during the experiment in control (O) and exposed (•) groups. See the text for the explanation of $C_{i}$ and $T_{1}$.

The relative weight of the heart to the body weight in the exposed group tended to be greater than that of the control group. This tendency was observed more clearly after the return to sea level than in the exposure period (Fig. 3).

Fig. 4 shows the correlation between $\mathrm{R}$ weight and $(\mathrm{L}+\mathrm{S})$ weight in both groups. The exposed group showed a notable increase in $\mathrm{R}$ weight in the first 3 weeks

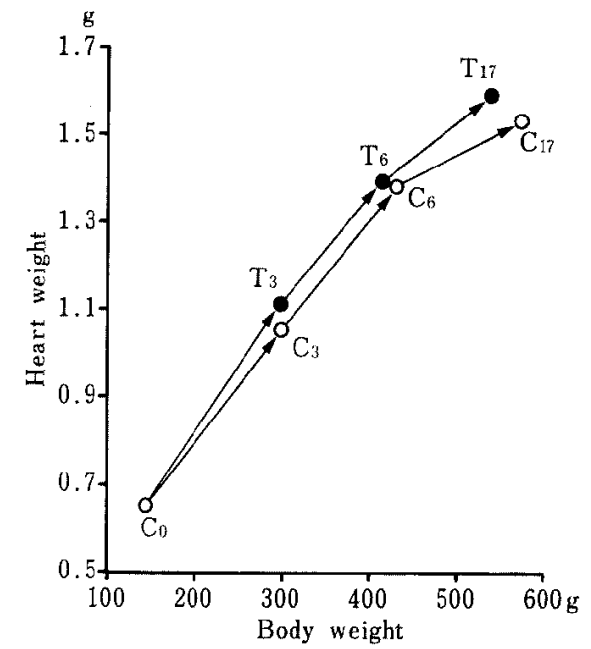

Fig. 3. Correlation chart of heart weight and body weight. Footnote is the same as in Fig. 2.

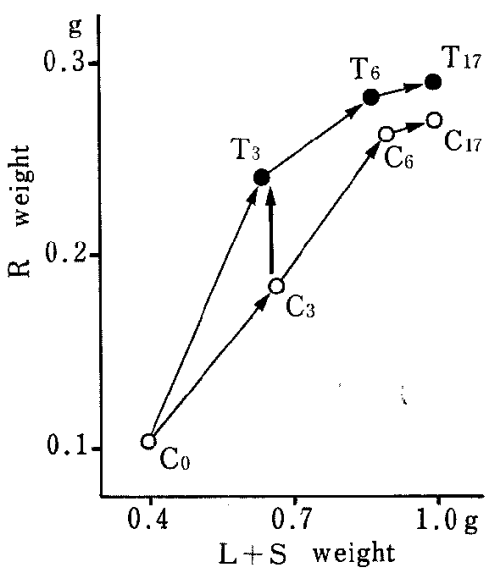

Fig. 4. Correlation chart of $\mathrm{R}$ weight and $(L+S)$ weight. See the footnote in Fig. 2. R: the right ventricular free wall, $L$ : the left ventricular free wall, $S$ : the ventricular septum. The vertical arrow indicates a significant difference in $R /$ $(L+S)$ ratio between $C_{3}$ and $T_{3}(P<0.05)$. 


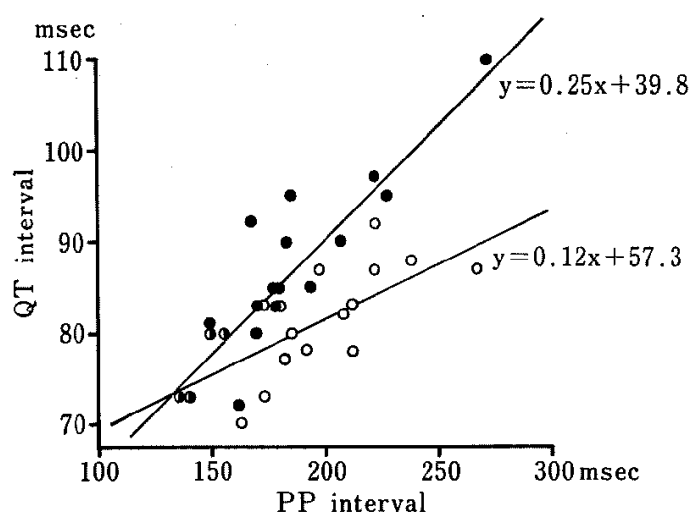

Fig. 5. Regression line of $\mathrm{PP}$ and $\mathrm{QT}$ intervals in control (O) and exposed ( $)$ groups. The data of $\mathrm{C}_{0}$ (O) were used for obtaining both regression lines.

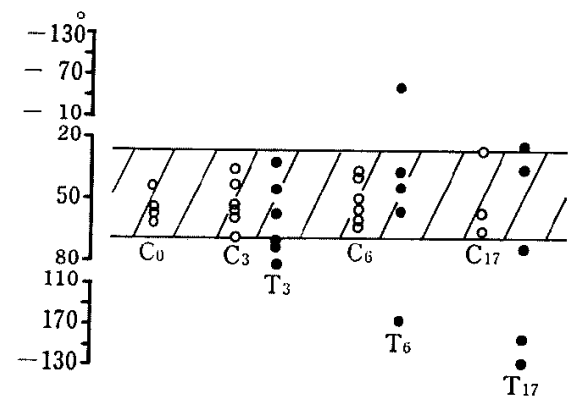

Fig. 6. Variation of mean QRS axis in control (O) and exposed ( $)$ groups. The hatched zone represents the maximalminimal range of the control group.

of exposure, as indicated by the large $R /(L+S)$ ratio of $T_{3}$.

Fig. 5 shows the regression lines of $\mathrm{PP}$ and $\mathrm{QT}$ intervals in both groups. The slope of the line in the exposed group was obviously greater than that in the control group $(\mathrm{P}<0.05)$.

The fluctuation of mean QRS axis in the control group was confined within a narrow range. On the contrary, the range of the exposed group was expanded especially in $T_{6}$ and $T_{17}$ as shown in Fig. 6.

The lung weight of the exposed group increased linearly, while the rate of increase for lung weight in the control group was depressed in $\mathrm{C}_{6}$. Therefore, the increase in lung weight due to exposure was accentuated after 6 weeks exposure $(\mathrm{P}<$ 0.05 ) as shown in Fig. 7.

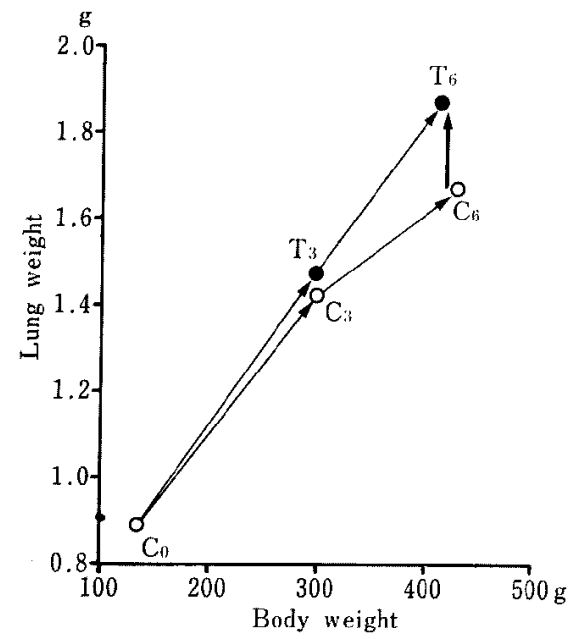

Fig. 7. Correlation chart of lung weight and body weight. See the footnote in Fig. 2. The vertical arrow indicates a significant difference in the lung/body weight ratio between $\mathrm{C}_{6}$ and $\mathrm{T}_{6}(\mathrm{P}<0.05)$.

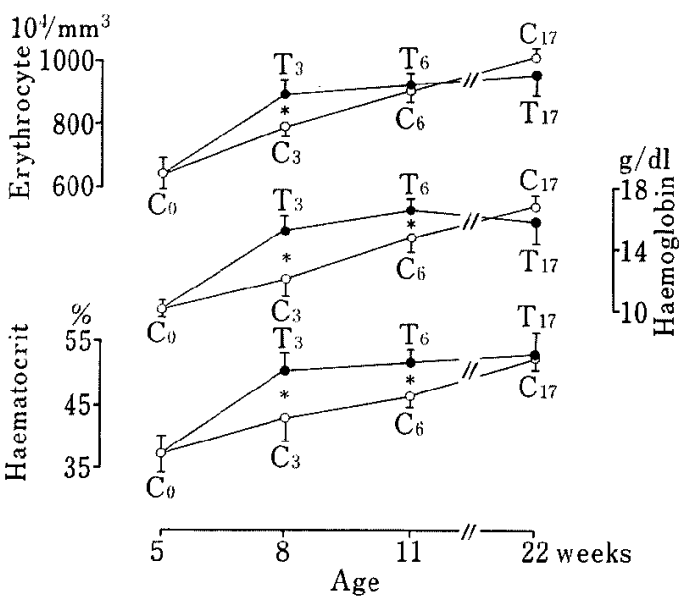

Fig. 8. Changes in blood properties in control $(0)$ and exposed ( $)$ groups. Each mark represents a mean \pm S. D.. * ; significant difference between control and exposed groups $(\mathrm{P}<0.05)$. 
Fig. 8 shows the process of changes in erythrocyte count, $\mathrm{Hb}$ concentration, and Hct value in both control and exposed groups. All measurements of these parameters in the exposed group were significantly larger than those in the control group at the $3 \mathrm{rd}$ week from the onset of exposure $(\mathrm{P}<0.05)$. However, the changes in these parameters in the exposed group leveled out thereafter.

\section{Discussion}

It has been reported in several works that adaptive changes in the heart occur in all individuals over $2,000 \mathrm{~m}$ altitude ${ }^{6}$, and cardiac failure appears over about $3,000 \mathrm{~m}$ altitude ${ }^{7}$. Based on these works, the conditions of high altitude simulation in this experiment were determined at $2,500 \mathrm{~m}$ altitude in order to observe with certainty the adaptive changes in the cardiopulmonary system.

From the depression in the gain in body weight in the exposed group, it was assumed that the simulative conditions of this experiment laid stress on the rats, as was also suggested by the process of changes in the adrenal weight.

Including the results obtained at the 11 th week from the return to sea level (22 weeks old), the changes in physiological parameters produced by the exposure were classified into two types: a reversible type represented by the changes in adrenal weight and blood properties, and an irreversible one represented by the changes in heart weight and mean QRS axis.

The increase in $\mathrm{Hb}$ concentration observed in the exposed group was considered to be an adaptive response to a hypoxic condition, since it meant an increase in the oxygen capacity of the blood ${ }^{8}$. The erythrocyte count of $T_{6}$ was no more different from that of $\mathrm{C}_{6}$, which suggests that the size and $\mathrm{Hb}$ content of the erythrocyte were changed. In fact, the values of $\mathrm{MCV}$ and $\mathrm{MCH}$ in $\mathrm{T}_{6}$ were greater than those in $\mathrm{C}_{6}$ $(\mathrm{P}<0.05)$. Therefore, the mechanism involved in the increase in $\mathrm{Hb}$ concentration was mainly due to the increase in the number of the erythrocytes in $T_{3}$, and due to the increase in $\mathrm{Hb}$ content of the erythrocyte in $\mathrm{T}_{6}$, respectively.

As it has been reported, an increase in Hct value can be considered to induce a high blood viscosity ${ }^{9)}$ and to increase the pulmonary vascular resistarce ${ }^{10)}$, and the occurrence of right ventricular hypertrophy is assumed by an increase in $R /(L+S)$ ratio $^{5)}$. In this experiment, considerable increases in both Hct value and $R /(L+S)$ ratio were observed in the first 3 weeks of the exposure. Moreover, the exposed group showed a prolongation of QT interval, which is often observed in cardiac hypertrophy. Therefore, it was presumed that the right ventricular hypertrophy had been produced in the exposed group owing to the increase in the pulmonary vascular resistance. The enlargement of the variation of mean QRS axis in $T_{3}$ may be connected with this right ventricular hypertrophy; on the other hand, the considerable enlargement in $T_{6}$ may have resulted from the alteration of the heart position in the thorax as suggested by the increase in lung weight.

In the present study, the high altitude simulation was performed by decompression alone in order to create hypoxic conditions under constant conditions of ambient tem- 
perature, relative humidity, $\mathrm{CO}_{2}$ concentration, and lighting. In general, the results obtained in this simulative experiment were similar to those observed in a natural high altitude environment composed of many meteorological factors in the aspects of morphological ${ }^{6,11}$, electrocardiographical ${ }^{12)}$, and haematological ${ }^{13,14)}$ changes. In our preceeding report ${ }^{4}$, we indicated that the main influential factor of a hypobaric-hypoxic condition on the cardiopulmonary function was the decrease in oxygen tension based on the observations in the rats exposed to hypobaric and/or hypoxic conditions. It was considered, therefore, that the most influential factor for the cardiopulmonary function of man and animals at high altitudes was the decrease in oxygen tension.

In this experiment, physiological parameters were altered by exposure, but the process of the alteration during the exposure was different for each parameter. For example, the initial changes evoked by exposure were great in the blood properties and the weight of the right ventricle in $T_{3}$, but the increase in lung weight or the enlargement of the variation of mean QRS axis appeared later in $T_{6}$. From the results obtained in this experiment, it was presumed that the animals altered their physiological conditions to achieve a new stable condition with the process of adaptation to a high altitude environment.

This work was supported by a Grant-in-Aid from the Ministry of Science, Education, and Culture of Japan (Grant No. 56480058).

\section{References}

1) Sawazak 1, H., Jpn. J. Zootech. Sci, 44: 451-459. 1973.

2) Sawazaki, H., H. Hirose, T. Kikuchi, T. Kyuma, S. Takizawa, M. Takahashi, M. Fuchimukai, T. Onodera, S. Saito, G. Katabira, and U. Yoshida, Jpn. J. Zootech. Sci., 46: 469-476. 1975. (in Japanese)

3) Furisancho, A. R., Human Adaptation. 101-138. The C. V. Mosby Company. St. Louis, Toronto, London. 1979.

4) Takemura, Y., S. Sugano, H. Hirose, and H. Sawazaki, Jpn. J. Zootech. Sci., 54: 755757. 1983.

5) Fulton, R. M., E. C. Hutchinson, and A. M. Jones, Br. Heart J., 14: 413-420. 1952.

6) Sawazaki, H., Jpn. J. Zootech. Sci., 44: 68-74. 1973.

7) Hecht, H. H., H. Kuida, R. L. Lange, J. L. Thorne, and A. M. Brown, Am. J. Med., 32: 171-183. 1962.

8) VAN Der Werf, T., Cardiovascular Pathophysiology. 256-260. Oxford University Press. New York, Toronto. 1980.

9) Shiga, T., J. Physiol. Soc. Japan, 44: 187-198. 1982. (in Japanese)

10) Barer, G. R., D. Bee, and R. A. Wach, J. Physiol., 336: 27-38. 1983.

11) Sawazaki, H., Jpn. J. Zootech. Sci., 43: 719-725. 1972.

12) Sawazaki, H., H. Hirose, T. Kikuchi, T. Kyuma, S. Takizawa, M. Takahashi, M. Fuchimukai, T. Onodera, S. Saito, G. Katabira, and U. Yoshida, Jpn. J. Zootech. Sci., 45 : 638-643. 1974. (in Japanese)

13) Kanematsu, M., K. Kibe, K. Sekigawa, S. Nomura, H. Sawazaki, Y. Shimizu, A. Oranda, and Y. Senoo, J. Jpn. Soc. Grassl. Sci., 14: 56 75. 1968.

14) Riar, S. S., K. S. Bhat, and J.S. Gupta, Int. J. Biometeor., 26: 129-136. 1982. 


\title{
低酸素環境が成長期ラットの心肺機能に及ぼす影響
}

\author{
竹村勇司・菅野 茂・広瀬 昶・澤崎 坦 \\ 東京大学農学部, 東京都交京区 113
}

慢性的な低酸素暴露が，成長期ラットの心肺機能に及 ぼす影響を明らかにするために，コントロールチャンパ 一を用いて寒験を行なった。

5 週令のWistar 䒺雄ラット 35 匹を7群に分けた. 5 週令で観察する群を $\mathrm{C}_{0}$ ，標高 $2,500 \mathrm{~m}$ 相当の低圧低酸

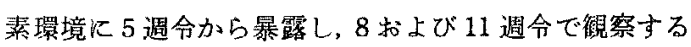
群を $\mathrm{T}_{3}, \mathrm{~T}_{6}, 11$ 週令まで暴露したのち海面相当の常圧 常酸素環境にもどし，22 週令で観察する群を $\mathrm{T}_{17}$ とし， それぞれの群に対して海面相当で飼育する 対照群 $\mathrm{C}_{3}$, $\mathrm{C}_{6} ， \mathrm{C}_{17}$ を設けた。 温度, 湿度, 括よび二酸化炭素濃度 はそれぞれ常に $25^{\circ} \mathrm{C} ， 60 \% ，$ および500〜 1,500 ppmに 制御した，各群に対して，形態的，心電図的，血液学的 検査を常王常酸素条件下で実施した.

暴露群では対照群と比べて，成長にとむなら体重の増
加が抑圧され，QT 間隔は延長し，心缄重量も大きい傾 向にあったが，暴露による副腎重量の増大は，常圧常酸 素環境へ戻すことにより回復した. 赤血球数, $\mathrm{Hb}$ 濃度, Hct 值，扣よび右心室重量は $\mathrm{T}_{3}$ 群で大きく増加したが， その後の増加は抑圧された． $T_{6}$ 群では，平均電気袖の バラッキが大きくなり, 肺重量体重比ならびに MCV, $\mathrm{MCH}$ が大きくなった.

高地環境下でみられる心肺系の典型的な変化が低酸素 暴露のみによって生じたことから，心肺機能にとって酸 素分圧の低下が多くの高地環境要因の中で最も重要な作 用因子であり，高地環境への適応過程として生理状態の 安定に向け段階的な変化が生ずる可能性が示暖された。

日音会報，55(7)：508-514，1984 